\title{
The Effect of Salinization in Maintenance of Intermittent Catheter
}

\author{
Nelly Lopes de Moraes Gil ${ }^{*}$, Izolete Aparecida Tomazine Santos ${ }^{2}$ and Maria Dalva de \\ Barros Carvalho ${ }^{3}$ \\ ${ }^{1}$ Universidade Estadual Paulista; São Paulo - SP - Brasil. ${ }^{2}$ Pós-graduação em Pesquisa e Desenvolvimento: \\ Biotecnologia Médica; FMB/UNESP; São Paulo - SP - Brasil. ${ }^{3}$ Curso de Enfermagem; Universidade Estadual de \\ Maringá; Maringá - PR - Brasil
}

\begin{abstract}
The aim of this study was to carry out a comparative analysis between the intermittent catheter, filled with heparin $100 \mathrm{U} / \mathrm{ml}$ and one filled with saline solution $0.9 \%$., by evaluating the formation of clots and quantifying them, when detected. Four groups of seven rabbits were used. In two of the groups, saline solution was used; in one group, in case of resistance, it was forced, whereas in the other, it was not forced. The other two groups were subjected to the same procedure, but, heparin solution was used. The presence of clot formation in all the groups was observed, independently of the solution used.
\end{abstract}

Key words: Intermittent catheter, heparin solution, saline solution

\section{INTRODUCTION}

The infusion medication IV provides direct entrance into the circulatory system. It is also an access for fluid and drug administration to the patients who cannot tolerate oral, intramuscular or subcutaneous medications (Weinstein, 1993). Therefore, it is the ideal medication to be used for absorption and fast reaction, in case of emergencies, when the doses of drugs need to be kept in the blood in therapeutical levels. It consists of an administration that offers comfort to the patient, thus preventing from repeated intramuscular injections, consequently, being one of the most used in the hospital environment.

The hydration through venous tract has been one of the most used, consisting of the best procedure for replacement of liquids and electrolyte. The patient usually needs parenteral medication, but no parenteral replacement of fluids. In this case, there is the option of using intermittent process medicines, without the necessity of maintaining the patient with the continuous venous solution. Such a technique brings benefits to the patient: a bigger comfort, mobility, reloading of liquid reduction, as well as, eases in movement (Garrelts et al., 1989). There are financial benefits for the institution, once it prevents expenses with equipment of continuous infusion and, consequently, liberates the team of nursing care to perform other activities (Abbott, 1981).

To use an intermittent peripheral venous access, it is necessary to make use of a peripheral intravenous device, through a scalp, also called winged set, infusion, or butterfly. "The winged" infusion consists of the puncture in a vein, with a

* Author for correspondence 
needle that possesses a pair of imprisoned plastic wings, attached to a flattened cannon. Nowadays, the peripheral venous puncture is, most of the times, made of a Teflon ${ }^{\circledR}$ catheter with a guide, just needing a connector in $\mathrm{Y}$ (polifix), so that it can be used in venous punctures (Phillips, 2001).

To make use of the intermittent catheter it is necessary to use one of peripheral intravenous device, adjusting the infusion of a solution that keeps the venous access permeable, and, adopting a systematic technique that provides safety to the patient and allows the nurse team to control its use, as well (Phillips, 2001). There are few papers referring to the salinization methods and/or heparinization of intermittent catheter, (Garrelts et al., 1989; Bobroff and Simonelli, 1994; Hanrahan et al., 1994; Rossetti et al., 1996; Mudge et al., 1998). However, the use of saline solution or solution of heparin did not present significant differences, although the heparin solution present advantages in relation to the saline solution (Hamilton et al., 1998). Experimental studies in rabbits showed in relation to hyperemia, permanence and blockage. Significant differences not exist in the permeabilization of the catheters with saline solution (Kyle and Turner, 1999). It is known that the heparin solution and the saline solution is used for the maintenance of the catheter permeability (Hamilton et al., 1998).

Currently, Intranenous Nurse Society (INS) recommends the use of intermittent catheter with 1 $\mathrm{ml}$ or more of sodic heparin solution 10 or $100 \mathrm{U}$, to keep the permeability of the vein. This solution is injected in the intermittent catheter each 8 hours, if the infusion is being kept (Fry, 1992). Anderson and Holland (1992) demonstrated that the heparin use of $10 \mathrm{U} / \mathrm{ml}$ was as effective as $100 \mathrm{U} / \mathrm{ml}$ to maintain the permeability of the central catheters peripherally inserted. The heparin solution is used, despite the high cost and no dilution. Also, in some types of procedures, this is not recommended, as for example, in patients during and after cerebral surgeries, or other ones, such as, spinal column, the eyes or in patients submitted to lumbar puncture and/or regional anaesthetic (O'Reilly, 1985).

The use of saline solution to keep the devices and catheters have been investigated due to counterindication in the use of the heparin in some cases, as in patients who present hemorrhage, thrombocytopenia, purpura, severe hipertension, intracraneal hemorrhage, bacterial endocarditis, active tuberculosis, ulcer lesion of the gastrointestinal treatment and visceral carcinoma, or in hemophilics (Rossetti et al., 1996). There are advantages in the infusion with physiological solution in relation to the infusion with heparin solution. It is incompatible with many other medications, and this means that it is necessary to carry out two other infusions with physiological solution: one before and another one after the administration of the medicine, thus, preventing to be in contact with the heparin solution (Rosseti et al., 1996). Therefore, the use of the permeable catheter with the heparin solution is considered unsafe, and, thus, with risk bleeding (Bowman, 1980).

However sodium chloride $(0.9 \%)$ can be as effective as sodic heparin in the maintenance of permeability of intermittent devices IV, although, they are still incomplete (Bowman, 1980).

The present study had main aim to compare the use of heparin solution $100 \mathrm{U} / \mathrm{ml}$ to the physiological serum $0.9 \%$ in the maintenance of the permeability of peripheral venous, during catheter intermittent use. Therefore, the evaluations in this comparative study were done by the following methods:

- If formation of blood clot existed, it would be evaluated during the catheter intermittent use;

- If blood clot existed, it would be quantified.

\section{MATERIAL AND METHODS}

\section{Material}

Twenty-eight adult male rabbits of the Norfolk ancestry, Botucatu variety, with weight varying between 2.5 and 3.0 Kilograms, obtained from the Hospital Veterinário de Medicine Veterinária e Faculdade de Zootecnia de Botucatu - UNESP were used. The animals were kept in separate river steamers, without food restriction with controlled illumination by timer, natural aeration in environment temperature and controlled humidity. The animals were weighed immediately before the experiment.

The catheter, 24 Gauge size, B Braun ${ }^{\circledR}$ make, consisted of a needle with a catheter at the top that was constituted of a cannula with 2.0 the $5.0 \mathrm{~cm}$ length, in pairs varying from 12 to 24 . After the puncture in the vein, the needle was removed and discarded, leaving a flexible catheter in the blood 
vessel. The canola material used in this experiment was polyurethane, a material of high resistance that confers a smooth surface for easy insertion to the catheter (Maki and Ringer, 1991).

A device for 2 ways multiple infusion (polifix), individually protected with fasteners in the entrance-ways, B Braun $\AA$ make, connected to the catheter was used (Fig. 2).

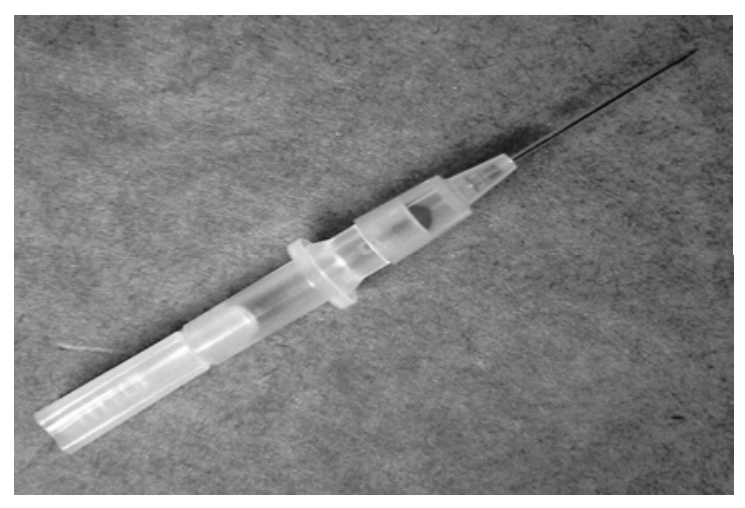

Figure 1 - An overview of the catheter on needle

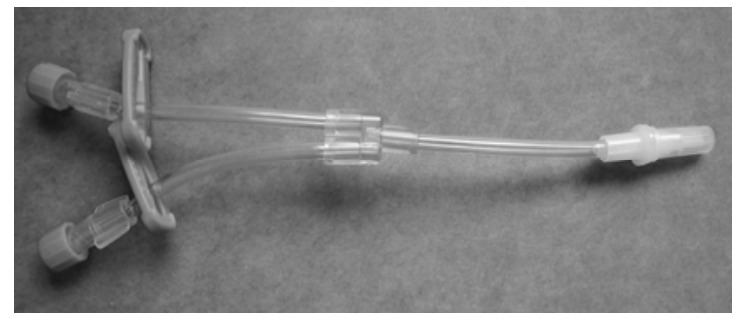

Figure 2 - An overview of a device for 2-ways multiple infusion (polifix).

The anaesthetic agent used was the sodic pentobarbital, infused by intramuscular in the dosage of $30 \mathrm{mg}$ per kilo of corporal weight.

The anaesthetic agent used was the sodic pentobarbital, infused by intramuscular in the dosage of $30 \mathrm{mg}$ per kilo of corporal weight.

The dosage used $(30 \mathrm{mg} / \mathrm{kg}$ per corporal weight) did not provide the ideal anaesthetic level to allow the accomplishment of the surgical procedure, but it was efficient for immobilization, to make the venous puncture and the setting.

\section{Methods}

The methodological sequence used was as the following:

I. The animals received a sedative medication, $3 \mathrm{ml}$ of a solution of sodic barbital Pento $3 \%$, applied into the intramuscular tract in the gluteus region by venous puncture;

II. The antisepsis of the ear was carried out with iodine pyrrolidone $(1 \%)$, in the inverse direction of the flur;

III. The puncture of the vein was made in the following way: the thicker vein of the ear was chosen and the catheter was inserted. The needle withdrawn and the connection to polifix was made, and, then fixed with appropriate tape (sparadrap) with the aid of a suitable syringe so that the ear could not fold. 


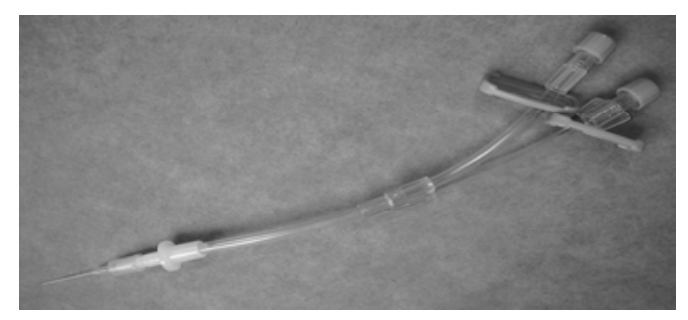

Figure 3 - Overview of a catheter hardwired to the polifix

\section{Experimental delineation}

In order to carry out the experiment, 28 rabbits were distributed in four experimental groups:

Group A1 - control group

Seven animals in which heparin solution, $(100 \mathrm{U} / \mathrm{ml})$, was used. In case of resistance during infusion, the solution was not infused.

Group A2 - control group

Seven animals, in which heparin solution, $(100 \mathrm{U} / \mathrm{ml})$, was used. Even in case of resistance during infusion, the solution was infused.

Group B1 - experimental group

Seven animals, in which physiological serum, $(0.9 \%)$ was used. In case of resistance during infusion, the serum was not infused.

Group B2 - Experimental group

Seven animals, in which physiological serum, $(0.9 \%)$ was used. Even in case of resistance during infusion, the serum was infused.

In all the animals, the auricular vein was punched with a catheter Gauge 24 with a two- wayconnection, kept for $72 \mathrm{~h}$, on accordance with CDC (Center of Disease Control). The catheter of the controlled animal groups A1 and A2 was filled with $3 \mathrm{ml}$ of heparin solution. After $12 \mathrm{~h}$, they were infused with physiological solution. After that distilled water infusion was made and again the physiological solution was used. After that infusion, the catheter was filled with $3 \mathrm{ml}$ of heparin solution. The heparin used in the study was the Liquemine ${ }^{\circledR}$ - Produtos Roche Químicos e Farmacêuticos S.A., São Paulo, Brasil. It was prepared using $0,1 \mathrm{ml}$ (100U) of diluted sodic heparin in $9,9 \mathrm{ml}$ of distilled water - dilution recommended by INS (Intravenous Nurse Society).

The catheter of the animals in the experimental groups B1 and B2 was filled with $3 \mathrm{ml}$ of saline solution and $12 \mathrm{~h}$, the distilled water infusion was made. Later, the catheter was filled with saline solution. The procedure was repeated each twelve hours, thus, simulating medication time.

\section{Statistical Analyses}

The comparative study on the effect of the salinization, on the maintenance of the intermittent catheter in the different experimental groups was carried out through the Kruskal-Wallis nonparametric test, with calculation of statistic $\mathrm{H}$ with $\mathrm{p}<0,05$.

\section{Approval of the Committee of Ethics in Research}

The project was approved by the Committee of Ethics in Research from 'Faculdade de Medicine de Botucatu (UNESP).

\section{RESULTS AND DISCUSSION}

The animals were evaluated at the following periods:

\section{Period 0 - M0}

Beginning of the experiment, the rabbits were divided into groups and anesthesiated. After that the biggest auricular vein was punched and the catheter was settled in the place of the insertion with sparadrap and, afterwards, a syringe holder was adapted so that the ears could be kept up thus, preventing, the blockage of the catheter.

Period 1 - M1

Evaluation was carried out $8 \mathrm{~h}$ after the puncture. The corresponding solution of each group was infused in each catheter. During this period no complications were observed.

Period 2 - M2

Evaluation was carried out $21 \mathrm{~h}$ after the puncture. 
The solution corresponding to each group was infused again. During this period some complications were observed.

Period 3 - M3

Evaluation was carried out $36 \mathrm{~h}$ after the puncture. When infusing the corresponding solution, more complications were observed.

Period 4 - M4

Evaluation was carried out $50 \mathrm{~h}$ after the puncture. When infusing the corresponding solution, some complications were observed.

Period 5 - M5

Evaluation was carried out $72 \mathrm{~h}$ after the puncture. That consisted of the final time of the experiment, with posterior withdrawal of the catheter.

No significant differences occurred in the variable regarding the groups or the moments.
In the evaluation carried out during M1, after the setting of the catheter, the following variables were analyzed:

- $\quad$ Presence of formation of blood clot;

- $\quad$ Length of blood clot;

- $\quad$ Fresh weight of blood clot;

- $\quad$ Dry weight of blood clot;

- $\quad$ Plaquetary counting;

- $\quad$ Feeling of discomfort.

\section{Presence of formation of blood clot}

Formation of blood clot was observed where blockage was found. It was evaluated by score: (0) without blood clot, (1) formation of blood clot, (2) blood clot in lumen.

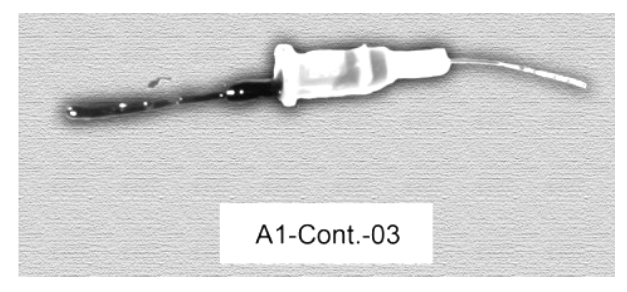

Figure 4 - Illustration of the size of blood clot removed from the catheter.

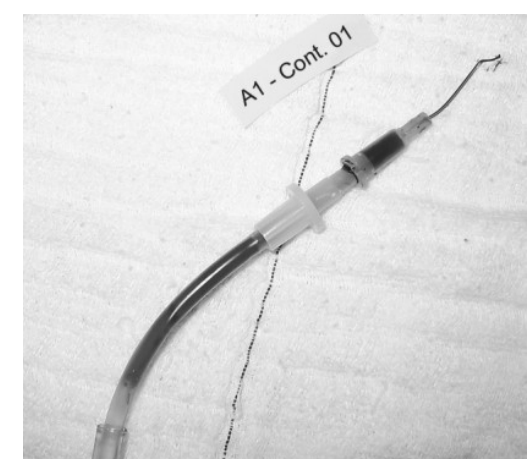

Figure 5 - Illustration of blood clot in lumen.

Group A1 - Control: Out of seven animals in this group, four $(57 \%)$ presented one thrombus, which was observed by the blockage found during the infusion.

This attribute was observed during M2, M3 and M4. In M1, the formation of blood clot was observed.

Group A2 - Control
Out of seven animals, five (71\%) presented a blood clot, which was observed by the blockage found during infusion. The infusion, in case of resistance, was evaluated by score with the following classification: $(0)$ without resistance, $(+)$ little, $(++)$ moderate and $(+++)$ high resistance. The attribute was scored during M2, M3 and M4. In M1 the formation of blood clot was not observed. 
Group B1 - Experimental

Out of seven animals, five (71\%) presented a blood clot, which was observed by the blockage found during the infusion. This attribute was observed during M2, M3 and M4.

Group B2 - Experimental

Out of seven animals, five (43\%) presented a blood clot, which was observed by the blockage found during the infusion. During the infusion, the resistance was evaluated by score, with the following classification: $(0)$ without resistance, $(+)$ little, $(++)$ moderate and $(+++)$ high resistance. Such attribute was observed at M2, M3 and M4 periods. In the M1 analysis, the formation of blood clot was not observed. The statistical analyses indicate no significant difference between the groups. However, groups A2 and B1 showed trends, $\mathrm{A} 2$ and $\mathrm{B} 1>\mathrm{A} 1>\mathrm{B} 2$.

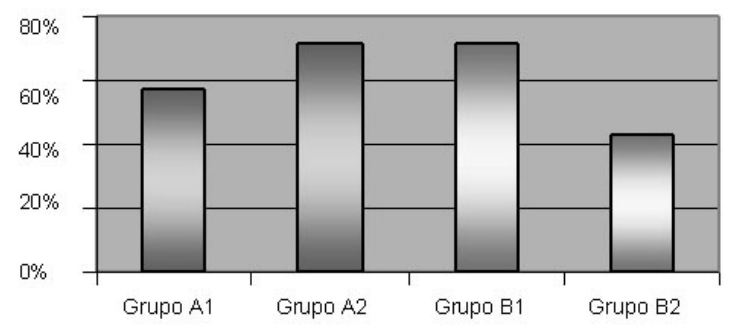

Graph 1 - Percentage of presence of blood clot formation in the different groups

The results indicated that filling the catheter either with heparin solution or with physiological solution not hinder the formation of blood clot which was different from the literature reports, which described the heparin solution with advantages over physiological solution (Hamilton et al., 1988).

The composition of the catheter (if the bevel was with sharp or not sharp tip) should be evaluated. The catheter, as well as, the needle must have smooth surface with silica in order to prevent a bigger trauma during the puncture, what lacerated the insertion place, thus, causing a bigger injury, propitiating the formation of blood clot. Therefore, the material used in the manufacture of the needle used in the composition of the catheter was as important as the filling solution. The maintenance of the positive pressure in the system of intermittent catheter which prevented blood reflow would be very important. Garrelts (1989) states that the formation of clots was more significant in the group with catheter filled with physiological solution than in the group of animals with catheter filled with heparin solution. The heparin solution reduced the incidence of formation of blood clot.

\section{Length of blood clot}

Group A1 - Control

Four animals $(57 \%)$ presented blood clot. The length was evaluated only in three, and the values varied from $0.4 \mathrm{~cm}$ to $2.5 \mathrm{~cm}$. In one of the animals, the blood clot lodged into the lumen of the catheter, then, it was no possible to perform the evaluation.

\section{Group A2- Control}

Five animals $(71 \%)$ presented blood clot. The length was evaluated only in two and the values varied from 1.2 to $3.0 \mathrm{~cm}$. The others three animals had presented blood clot lodged in the lumen of catheter.

Group B1 - Experimental

Five animals $(71 \%)$ presented blood clot. The length was evaluated only in two, and the values varied from 0.6 to $3.5 \mathrm{~cm}$. The other two animals presented blood clot lodged in the lumen of catheter.

\section{Group B2 - Experimental}

Two animals (28\%) presented blood clot. The length was evaluated only in one of them, and that was $1.7 \mathrm{~cm}$. The other animal presented blood clot lodged in the lumen of catheter.

It was observed that groups A2 and B1 presented more animals with blood clot detected. Group B2 experimental presented the smallest number of animals with blood clot. It was also noticed that existed a high dispersion in the length of blood clot, presenting a variation coefficient of $70.66 \%$.

\section{Fresh weight of blood clot}

The weight of blood clot did not present significant difference in relation to the groups. 


\section{Dry weight of blood clot}

The dry weight of blood clot did not present significant difference in relation to the groups. The results of the statistical analysis referring to the weights of the dry thrombus had not differed from the results of the weight analysis of fresh thrombus.

\section{Plaquetary counting}

In groups A1, A2, B1 and B2, the medium count of platelet had normal values at M2 and M4. There were no significant statistics differences.

\section{Discomfort}

Group A1 - Control

There was no discomfort during infusion.

Group A2-Control

It was observed that when the resistance was forced, the animal felt a sort of discomfort.

Group B1 - Experimental

Discomfort was not observed at any period of the infusion.

Group B2 - Experimental

It was observed that when the resistance was forced, the animal felt a discomfort. Regarding the discomfort, there was a significant variation between the groups, but related to the resistance, no with regard to the filling the solution. It was noticed that the attribute discomfort did not appear in groups A1 and B1, in which, the solution was not infused when resistance occurred. The attribute appeared in groups A2 and B2, in which, even when resistance occurred, the solution was infused.

(Hamilton et al., 1988) described an experiment where the group, whose catheter was filled with heparin solution (13\%), felt discomfort. But, on the other hand, in the group, whose catheter was filled with saline solution $(14 \%)$, pain was observed.

Based on the present study, it was presumed that the formation of blood clot existed during the use of intermittent catheter, as well as, it exists either with the filling with heparina solution or with physiological solution $(0.9 \%)$. The size of the formed blood clot varied in the same way with the use of heparin solution as with the physiological solution.

- Group B2, in which physiological solution was infused even with resistance, presented a decrease in the number of animals with formation of blood clot.
- At M1 there were no complications, thus, suggesting that the intermittent catheter could be kept for a period of $8 \mathrm{~h}$.

\section{RESUMO}

O uso de cateter intermitente representa um procedimento muito utilizado em ambiente hospitalar. Este estudo, de natureza experimental, teve como propósito a análise comparativa entre o cateter intermitente, preenchido com solução de heparina $100 \mathrm{U} / \mathrm{ml}$ e o preenchido com soro fisiológico $0,9 \%$. Foi realizado um estudo comparativo, avaliando a formação de coágulos e se estes estivessem presentes seriam quantificados. Para tanto, foram utilizados quatro grupos de 7 coelhos, da linhagem Norfolk, sendo realizado acesso venoso em veia auricular conectado ao dispositivo de infusão múltipla. Em dois destes grupos, foi usada solução salina; em um grupo, caso fosse encontrada resistência, esta seria forçada; no outro, esta resistência não seria forçada. Nos dois outros grupos, foi usada solução de heparina; em um grupo, caso fosse encontrada resistência, esta seria forçada; no outro esta resistência não seria forçada. $\mathrm{O}$ cateter intermitente foi mantido por 72 horas e, a cada 12 horas foi infundida água destilada, simulando a administração de medicamento. Durante o experimento foram observadas as seguintes variáveis: presença da formação de coágulos, comprimento do coágulo, peso fresco do coágulo, peso seco do coágulo, contagem plaquetária e desconforto. $\mathrm{Na}$ análise estatística feita pelo método não paramétrico Kruskal-Wallis, com nível de significância de $\sigma=5 \%$, não foi encontrada diferença significativa entre os grupos e momentos. Pôde-se constatar a presença de formação de coágulo em todos os grupos independentemente da solução de preenchimento. Concluímos, principalmente, que há necessidade de elaboração de novas normas e rotinas na utilização de cateter intermitente.

\section{REFERENCES}

Abbot. Divisão hospitalar, terapia IV intermitente: uma nova perspectiva. Illinois Abbot Laboratories, 1981. 
Anderson, M.; Holland, J. Maintaining the patency of peripherally inserted central catheteus with 10 units/cc heparin. J. Intravenous Nurs. v.15, n.2, p.8488,1992 .

Associação Paulista De Estudos De Controle De Infecção Hospitalar. Orientações para o controle de infecções em pessoal da área da saúde. São Paulo: APECIH, 1998. 94p.

Barret, P.J.; Lesler, R.L. Heparin vs saline flushing solutions in a small community hospital. Hosp. Pharm. n 25,p.115-118, 1990.

Bennet, J. S. Mechanisms of platelet adhesion and aggregation: an update. Hosp. Pract. (Off. Ed.) v.27, n.4, p.124-126, 1992.

Bobroff, M.C.C.; Simonelli, M.L. Hidratação: técnica alternativa de punção e manutenção de scalp. Semina: Cienc. Biol. v. 15, 1994.

Bowman, W.C. The Blood. In: Bowman, W.C.; Rand, M.J. The textbook of pharmacology. 2.ed. Oxford: Blackwell, 1980.

Capra, F. A teia da vida: Uma nova compreensão científica dos sistemas vivos, 5.ed. São Paulo: Cultrix, 1996. 256p.

Carter, C. J. Pathogenesis Of Arterial Thrombosis. In: Hull, R.; Pineo, G.F. (eds.) Disorders of thrombosis. Philadelphia : W.B.Saunders Company, 1996.

Centers For Diseasa Control And Prevention. Guidelines For Prevention of Intravascular Catheter related infections. Morb. Mortal. Wkly. Rep., v.51 (RR-10) p.1-129, 2002.

Cosnett, J. E. The Origins of intravenous fluid therapy, Lancet, v.1, p. 768-771, 1989.

Couto, R.C.; Pedrosa, T.M.G.; Nogueira, J.M. Infecção hospitalar epidemiologia,e controle gestão para a qualidade.2ed. Rio de Janeiro: MEDSI, 1999. p. 387399.

Crossley, K. ; Matsen, M. The scalp- vein needle. A prospective study of complications. JAMA, v.220 n.7, p.985-987, 1972.

Davie E. W. Biochemical and molecular aspects of the coagulation cascade. Thromb Haemost, v.74,n.1, p.16, 1995.

Epperson, E.L. Efficacy of 0,9\% sodium chloride injection with and without heparin for maintaining indwelling intermittent injection sites. Clin. Pharm. v.3, n.6, p.626-629, 1984.

Fry, B. Intermittent Flushing protocols: a standardization issue. J. Intravenous Nurs.v.15, n.3, p.160-163, 1992.

Garrelts, J.C.; La Rocca, J.; Ast, D.; Smith, D.F. Jr; Sweet D.E. Comparison of heparin and $0.9 \%$ sodium chloride injection in the maintenance of indwelling intermittent i.v. devices. Clin. Pharm., v.8, n.1, p. 3439, 1989.

Gyton, A. C. Tratado de fisiologia médica. 9 ed. Rio de Janeiro: Guanabara Koogan, p.830-843, 1996.
Hamilton, R.A.; Plis, J.M.; Clay, C.; Sylvan, L. Heparin sodium versus $0.9 \%$ sodium chloride injection for maintaining patency of indwelling intermittent infusion devices. Clin. Pharm., v.7, n.6, p. 439-443, 1988.

Hanrahan, K.S.; Kleber, C.; Fagan, C.L. Evaluation of saline for i.v. locks in children. Pediatr. Nurs. v.20, n.6, p.549-552, 1994.

Jandl, J. Blood Textbook of Hematology. Boston: Little Browm and Co.,1987, 1214 p.

Junqueira, L.C. ; Carneiro, J. Histologia básica. 7. ed. Rio de Janeiro: Guanabara, 1991. 388p.

Kyle, L.A.; Turner B.S. Efficacy of saline vs heparin in maintaining 24-gauge intermittent intravenous catheters in a rabbit model. Neonatal Netw., v.18, n.6, p. 49-54, 1999.

Magalhães, H.P. Técnica cirúrgica e cirurgia experimental. 3ed. São Paulo: Savier. P, 1989. p. 6376.

Maki, D. G. ; Ringer, M. Evaluation of Dressing Regimens for Prevention of Infection with Peripheral Intravenous Catheters, JAMA, v. 58, p.2396, 1987.

Mudge, B.; Forcier, D.; Slattery, M.J. Patency of 24gauge peripheral intermittent infusion devices: a comparison of heparin and saline flush solutions. Pediatr. Nurs. v. 24, n.2, p. 142-145, 1998.

Nettina, S. M. Pratica de enfermagem. 6 ed. Rio de Janeiro: Guanabara Koogan, , 1998. p 55 -59.

O'reilly, R.A. Drugs used in disorders of coagulation. In: Katzung, B.G. Basic and Clinical Pharmacology. $2^{\mathrm{a}}$ ed. Ed. California: Lange, 1984. Cap. 32.

Phillips, L.D. Manual de terapia intravenosa. $2^{\mathrm{a}}$ ed. Porto Alegre: Artmed, 2001.

Rodrigues, E. A.C.; Mendonça, J.S.; Amarante, J.M.B.; Grimbaum, R.S.; Ritchtmann, R. Infecções hospitalares: prevenção e controle. São Paulo:, Savier, p. 411-421, 1997.

Rosseti, A.C.; Melo, J.C.F.; Oliveira, L.P.; Rosa, M.B.F.; Cabestré, M.C.; Souza, M.L.F; Gomes, P.C. Experimento sobre uso de soro fisiológico para manutenção da permeabilidade de cateteres venosos periféricos de uso intermitente. In: ENFETEC. 5., 1996, São Paulo, 1996.

Smeltzer, S.C. Brunner and Suddarth. Tratado de Enfermagem Médico Cirúrgica. 8ed., Rio de Janeiro : Guanabara Koogan, p. 204-206, 1999.

Weinstein, S. Plumer's principles and practice of intravenous therapy. 5 ed. Philadelphia: J.B. Lippicott, 1993.

Williams, W. Hematology 4 ed. New York: Mc Grawhill, 1990. 